\title{
GASTROPOD SHELL ULTRASTRUCTURES - ADJUSTING A SEARCH IMAGE
}

HEDEGAARD, Claus, Institute of Biology, Department of Genetics and Ecology, University of Aarhus, 8000 Aarhus C, Denmark, and, Museum of Paleontology, University of California, Berkeley, CA 94720, USA

Since the turn of the century we have perceived shell structures of the ancestral gastropod to be nacreous and simple prismatic, though this view is based rather on tradition than critical analysis of the characters. Shell ultrastructures, the three dimensional organization of lime and organic material in shells, provide important phylogenetic information. Fractured sections of shells from adult mollusks, examined by scanning electron microscopy, reveal one or several layers, each with one of 15-20 different shell structures. Shell structures are invariant within clades and different between clades, and excellently suited for phylogenetic analysis. Some clades are characterized by a homologous sequence of layers, which may be analyzed as other sequential information (DNA, proteins). Aragonitic crossed lamellar structure is an apomorphy for the clade Mollusca; intersected crossed platy structure is a vetigastropod apomorphy, whereas columnar nacre is confined to a subclade of the Vetigastropoda; prismatic complex crossed lamellar structure is found in Acmaeidae and Lottidae, foliated structure in Acmaeidae, Nacellidae and Patellidae, calcitic crossed lamellar in Lepetidae and Patellidae. One of the interesting results is that nacre (mother-of-pearl) does not characterize "primitive" gastropods nacreous gastropods do not occur close to the base of most parsimonious trees, depicting gastropods' infered descent, nor is there any indication that those actually on early branches (Patellogastropoda) have nacreous ancestors. The impact on palaeomalacology is to spur an adjustment of our search image of ancestral gastropods to shells with crossed lamellar structures. 